DOI https://doi.org/10.36059/978-966-397-178-0/49-65

\title{
THE RATIO OF THE CIVIL AND CIVIL-PROCEDURAL LEGAL RELATIONS IN THE SCIENCE OF CIVIL PROCEDURAL LAW
}

\section{Didenko L. V.}

\section{INTRODUCTION}

In society there is always a wide variety of relationships between people and their associations, resolved or not resolved rules of law: economic, political, moral, spiritual, cultural, civil, family etc. The scientific relationship between them is often related to such categories as "activity", "user", "rule of law". In addition, different types of relationships differ. The issue of cooperation between civil law and civil procedure relations is new for the domestic legal science, which today is civilized and considers issues that do not consider the issue in such a context. So far, the ratio of civil and civil procedural legal relations has not been carried out within the framework of scientific research. At the same time, a number of scientists carried out comparisons of categories of civil and civil procedural law, civil law and civil procedure norms, and also established the concept of civil law and civil procedure legal relations, the definition of the essence of which makes it possible to correlate both categories. Such researchers include, first of all, such as: I.S. Andriyenko, Y. Belousov, S. Vasiliev, A.V. Getmantsev, K.V. Gusarov, T.M. Kilichawa, V.V. Komarov, Z. Lazko, A.L. Paskar, A.V. Pidlubnaya, P.I. Radchenko, L. Tychynski, E.I. Fursa, S.Y. Fursa, T.V. Tsyura, S.I. Chernoochenko, M.I. Stefan, S.V. Scherbak, M.M. Yasinok etc. However, directly establishing the relations between the civil law and civil procedural legal relations in scientific research by these authors was not done, which determines the relevance of research on a given topic.

\section{Relationship between civil law and civil procedural law}

Ratio is the mutual relation, mutual connection, mutual dependence of different values, objects, events. That is, setting the ratio civil-law and civilprocedural relations, we are primarily defined by their mutual relation to each other, mutual connection and dependence.To establish this relationship, you first need to figure out how to relate to civil procedure law and civil law, because the regulatory force of their norms revealed in the regulation of appropriate relations. The expediency of the study of the ratio of civil procedure and civil law is also confirmed in the work of A.V. Podlubnyi, who, by correlating civil procedure norms and civil legal relations, came to the conclusion that they are interrelated forms of law existence. The norm of law 
transforms public relations into legal, that is, a prerequisite for the emergence of legal relations, and the latter, in turn, is a way to implement in practice the norms of law and help the norms to influence public relations. In other words, the norms of civil procedural law are the primary links of the system of civil process, one of the ways of implementation of civil procedural relations in practice and a tool through which the impact on public relations is carried out ${ }^{1}$. Taking into account the interconnectedness of civil procedural norms and civil legal relations, we conclude that it is advisable to analyze the relationship between civil procedural law and civil law in order to achieve the goals of this study.

Thus, M.I. Stefan notes that the link between civil procedural law and civil and other branches of substantive law is determined by the need to enforce the norms of substantive law by the judiciary. That is, civil procedural law is a form of ensuring the vital activity of the norms of substantive law, protection and their enforcement. In particular, part 1 of Article 19 of the current Civil Procedural Code of Ukraine states that the courts consider in the order of civil proceedings cases arising from civil, land, labor, family, housing and other legal relations, except for cases, consideration of which is carried out in the order of other legal proceedings. Also, as noted by M.I. Stefan, the link between civil procedure and civil law is manifested in the existence of a coercive apparatus capable of enforcing compliance with the norms of civil law - the court, the order of which is regulated by the norms of procedural law in the consideration and resolution of civil cases; as well as in certain norms and institutions of civil law - in particular, those that determine the circumstances, the totality of legal facts that constitute the basis of the claim, the subject of proof and are subject to clarification in civil proceedings when considering specific references ${ }^{2}$. From all of the above we can conclude that the relationship between civil and civil procedural legal relations, according to the position of M.I. Stefan, is as follows:

1) civil procedural legal relations arise in the presence of disputable nature in civil legal relations;

2) in the case when the subject of civil legal relations is a court, such legal relations turn into civil procedural ones. At the same time, the activities of the court are regulated by the norms of civil procedural law, and the cases that are considered by it are regulated by the norms of civil law;

${ }^{1}$ Теоретичні проблеми цивільного процесуального права : підручник / М. М. Ясинок, М. П. Курило, О. В. Кіріяк, О. О. Кармаза, С. І. Запара та ін.; за заг. ред. д.ю.н. професора М. М. Ясинка. К. : Алерта, 2016.

${ }^{2}$ Штефан М. Й. Цивільне процесуальне право України : академічний курс. К. : Ін Юре, 2005. 624 c. 
3) separate norms and institutions of civil law, respectively, are related to civil legal relations, as they determine the circumstances, the totality of legal facts that constitute the basis of the claim, the subject of evidence and are subject to clarification in civil proceedings in the consideration of specific cases.

Thus, guided by the above analyzed point of view, we can conclude that civil procedural and civil legal relations are related as a prerequisite and consequence. The existence of civil procedural legal relations is not a primary need, except in cases where coercion is necessary in civil legal relations. These legal relations differ, above all, by their subjective composition. After all, when the party to the relationship becomes a court, such legal relations can be defined only as civil procedural. Certain relations are also observed in the legal regulation of both types of legal relations, because it is the norms of civil law that determine the legal facts that are subject to clarification in civil procedural legal relations. The authors of the book "Theoretical Problems of Civil Procedure Law" under the general editorship of M.M. Yasinka explain that the ratio of civil and civil procedure law is that civil procedure law is a form of law, ensures the life of norms of civil law, protection and their enforcement ${ }^{3}$. At the same time, the researcher notes that civil procedural law without civil (or other material) law would become meaningless and lose its social and legal meaning. This position is very close to the previous one analyzed. However, we emphasize that from this point of view, the relationship between civil and civil procedural law lies in the mutual dependence of individual provisions of civil law institutions and civil procedural law. In particular, as well as in the opinion of M.I. Stefan, their ratio is that the norms of civil law determine the grounds for appeal to the court, the parties to the civil process, the range of circumstances to be proved, the rules of jurisdiction, and, accordingly, the norms of civil procedural law are the procedural order of such appeal, the types of evidence and the order of proof. However, the authors emphasize that not only the functioning of civil law depends on the procedural law, but also the existence of civil procedural law without civil law loses its sensor. Taking this into account, we can somewhat expand the conclusions made earlier in this paper on the relationship between civil and civil procedural legal relations, namely, that the links and interdependence of civil procedural legal relations and civil legal relations are two-way: civil procedural legal relations arise in the presence of a controversial nature in civil legal relations and at the same time, due to the existence of civil procedural legal relations, the life of civil legal relations is ensured, their protection, as well as their enforcement.

${ }^{3}$ Цивільний процес України : підруч. / В. О. Кучер та ін.; ред. В. О. Кучер. Львів : ЛьвДУВС, 2016. 768 с. 
Other researchers (e.g. L. Tichinska) agree with such conclusions, but do not offer alternative views ${ }^{4}$.

Thus, in the process of analysis of the scientific literature devoted to the ratio of civil and civil procedural law, we have established that civil and civil procedural legal relations are related as follows:

1) 1)relations between civil law and civil procedural legal relations are bilateral - civil procedural legal relations arise in the presence of a controversial nature in civil legal relations, and due to the existence of civil procedural legal relations, the life of civil legal relations is ensured, their protection and enforcement;

2) 2)when the court enters into civil legal relations, such legal relations turn into civil procedural ones. At the same time, the activities of the court are regulated by the norms of civil procedural law, and the cases that are considered by it are regulated by the norms of civil law;

3) certain norms and institutions of civil law are also relevant to civil procedural legal relations, because they determine the circumstances, the totality of legal facts that constitute the basis of the claim, the subject of proof and are subject to clarification in civil proceedings in the consideration of specific cases: The norms of civil law define the grounds for appeal to the court, the parties to the civil process, the range of circumstances to be proved, the rules of jurisdiction, and accordingly the norms of civil procedural law are the procedural order of such appeal, the types of evidence and the order of proof.

We conclude that the above features are sectoral criteria for the ratio of civil law and civil procedural legal relations, because their allocation follows from the features of the ratio of branches of law, within which they are implemented. However, the ratio consists not only in establishing mutual relations and mutual dependence of different phenomena or concepts. The ratio also consists in defining the distinguishing features that distinguish one institution from another. Therefore, we propose to distinguish special criteria of differentiation between civil and civil procedural legal relations, the essence of which follows from the legal nature of each of the institutions. For example, N.Y. Golubeva, studying the ratio of mandatory and proprietary legal relations, defined the following criteria by which they differ from each other: 1) by the circle of related persons; 2) by the object; 3 ) by the grounds of origin; 4) by the specific form in which the rights and respective obligations of the parties are expressed; 5) by the peculiarities of subjective law; 6) by the

\footnotetext{
${ }^{4}$ Тичинська Л. А. Правові засади цивільного процесуального права: співвідношення 3 іншими галузями права в умовах розбудови правової держави. Європейські перспективи. 2014. № 4. C. 121-123.
} 
nature of implementation; 7) by the peculiarities of legal regulation; 8) by the value for civil turnover; 9) by the time of existence; 10) if necessary, the interaction of the parties; 11) by property or non-property nature ${ }^{5}$.

The following conclusions will be drawn from this position:

1) 1)it has enough general character, that is it can be applied not only for an establishment of parities between obligatory and material legal relations, but also for differentiation of civil and civil procedural legal relations or other kinds of legal relations;

2) 2)since the ratio of different types of legal relations does not enjoy popularity among domestic scientists, we propose to be guided in our study by the majority of the above-mentioned criteria, except for those that are more of a special nature (for example, the establishment of a ratio of civil law and civil procedural legal relations on the meaning for civil turnover does not seem to be appropriate and possible).

Thus, our research allows us to conclude that the ratio of civil and civil procedural legal relations should be carried out according to the following criteria:

1) by the circle of persons related to them;

2) by object;

3) on the grounds of occurrence;

4) in a specific form in which the rights and respective obligations of the parties are expressed;

5) by peculiarities of subjective law;

6) by the nature of the subjects' exercise of their rights;

7) on peculiarities of legal regulation;

8) by the time of existence;

9) if necessary, interaction between the parties;

10) by legal nature (property or non-property).

\section{Criteria for the ratio of civil law and civil procedural relations}

Accordingly, to determine how is the relationship of civil and civilprocedural legal relations, it is worth to analyze the characteristics of each of them within selected guidelines.

1. In a circle of related persons. A.S. Mazur notes that each civil legal relationship involves at least two subjects, which are its participants, who are also called persons. The subject of civil legal relations, to which the right belongs, is called the subject of law, and the subject of civil legal relations, to

5 Діденко Л. В. Співвідношення цивільно-правових та цивільно-процесуальних відносин. Науковий вісник Ужгородського національного університету. Серія: Право. 2016. Вип. 41. Т. 4. С. 146-149. 
which the duty is assigned - a passive subject. In civil legal relations, each of the participants has subjective rights and bears subjective duties (for example, in civil legal relations arising from contracts of sale, each of the subjects of legal relations has rights and bears duties) and should be a legal entity, that is, possess the ability to be a party to civil legal relations. A.S. Mazur also points out those subjects that may be participants of civil legal relations - citizens of Ukraine, foreign citizens, stateless persons, legal entities (state enterprises and institutions, cooperatives, public organizations, joint-stock companies, rental companies), the state of Ukraine, other organizations (for example, religious organizations, joint ventures with the participation of Ukrainian and foreign legal entities, foreign enterprises and organizations). That is, in this case, we note the absence of special subjects that are unique to this type of legal relations. In general terms, there is a wide range of persons who are subjects of civil law.

As for the subjects of civil and procedural legal relations, the analysis of the norms of Chapter 4 of the Civil Procedural Code of Ukraine shows that they are primarily related to them ${ }^{6}: 1$ ) participants of the case (including presbyters of the parties); 2) other participants of the trial. However, as the author of the textbook "Theoretical Problems of Civil Procedure Law" under the editorship of M.M. Yasynka aptly points out, civil procedure law does not distinguish the court or bodies administering justice as a separate group of subjects, however, based on the constitutional provisions on legal proceedings and general principles of justice, we can conclude that it is the court that will play a leading and decisive role in the judicial process. That is why the third group of subjects of civil procedural legal relations should include the court as a subject whose exclusive function is the administration of justice. Analysis of the provisions of Chapter 3 of the Civil Procedural Code of Ukraine shows that this group of subjects belongs to this group: 1) a judge is a sole person who is the chairman and acts on behalf of the court; 2) a collegial composition of the court consisting of one judge and two jurors; 3 ) a collegial composition of the court of appeal consisting of three judges; 4) a collegial composition of judges of the court of cassation consisting of three or more odd number of judges; 5) a judicial chamber of the Civil Court of Cassation (chamber), a united chamber of the Civil Court of Cassation (united chamber) or the Grand Chamber of the Supreme Court (the Grand Chamber). Participants in the case are individuals and legal entities, the State of Ukraine, the Autonomous Republic of Crimea, territorial communities, foreign states, public authorities (central and local), local governments, public authorities of the Autonomous Republic of Crimea, public institutions (foundations and institutions), public

${ }^{6}$ Цивільний кодекс України : Закон України від 16.01.2003 № 435-IV. Відомості Верховної Ради Украӥни. 2003. № 40. Ст. 356. 
institutions (foundations and institutions), public and public enterprises, public utilities. Such a conclusion can be made taking into account the subjects of civil legal relations.

Any subject of civil legal relations can become a subject of civil procedure if there is a need to protect violated, unrecognized or disputed rights, freedoms or legitimate interests.

At the same time, the subjects of civil procedural relations can be much wider circle of people. According to article 56 of the CPC of Ukraine to subjects should include bodies and persons who legally have the right to go to court in the interests of other parties (state authorities, local self-government bodies, physical persons and legal entities, the Ukrainian Parliament Commissioner for human rights), as well as representatives. Other participants, in accordance with paragraph 3 of Chapter 4 of the CCP, is the assistant judge, court clerk, court bailiff, witness, expert, expert on law, a translator, a specialist.

So, correlating civil and civil procedural legal relations on criterion of a circle of the persons connected by them, we come to a conclusion that in civil procedural legal relations the wider circle of persons can participate much wider. Specific subjects are, first of all, the court as a subject, the exclusive function of which is the administration of justice, bodies and persons, which by law are granted the right to appeal to the court in the interests of other persons and representatives. Also, the subjects of civil and procedural legal relations should include a special category of subjects who are participants in the trial, but are not parties to it - assistant judge, secretary of the court session, court administrator, witness, expert, legal expert, interpreter, specialist.

2. The object. The object in general theoretical understanding is a phenomenon, a subject, a person to which a certain activity aspires, attention is longing. That is, the object of legal relations is what they arise and exist for. V.I. Borisova, I. Spasibo-Fateeva, and V.L. Yarotsky note that the issue of the object of civil legal relations is one of the most complicated in the theory of civil law. Since all civil legal relations arise in relation to a certain property or non-property benefit, the Civil Procedure Code of Ukraine singles out the property object of civil legal relations and non-property object ${ }^{7}$. Property objects of civil legal relations are: 1) things; 2) money; 3) securities; 4) property rights, results of some types of human activity (works and services - for example, a house was built, a thing, a costume was repaired, etc.). Non-material objects of civil legal relations are referred to as non-property objects: 1) results of

${ }^{7}$ Цивільний процес України : підруч. / В. О. Кучер та ін.; ред. В. О. Кучер. Львів : ЛьвДУВС, 2016. 768 с. 
human intellectual activity or objects of intellectual property rights (works of science, literature, art, discoveries, inventions, etc.); 2) information; 3) personal non-property benefits (honor, dignity, business reputation, name, image, privacy, etc.). Accordingly, in general terms, civil procedure relations arise in relation to these very benefits, but in this case they are not the object of legal relations. As defined by T.M. Kilichava, the object of civil procedural legal relations is the public relations on protection of the violated material right or interest protected by the law in court. It follows that civil legal relations arise in relation to a certain property and personal non-property right or interest protected by law. In turn, the basis for the emergence of civil procedural legal relations is the violation of such a right. That is, according to the criterion of the object of legal relations, civil and civil procedural legal relations are related as a prerequisite and as a consequence. It is impossible to violate this right or interest without the occurrence of a corresponding right or interest. Accordingly, the protection of violated rights and interests is the only object of civil and procedural legal relations ${ }^{8}$.

3. On the grounds of origin. It is generally accepted that any legal relations arise, change and terminate on the basis of legal facts, i.e. certain circumstances and facts of reality. Thus, the legal fact is the main condition for the emergence of both civil and civil procedural legal relations. The list of legal facts, with the onset of which the emergence of civil legal relations, is enshrined in Article 11 of the Civil Code of Ukraine, and they are referred to them: 1) contracts and other transactions; 2) creation of literary, artistic works, inventions and other results of intellectual activity; 3) infliction of property (material) and moral damage to another person; 4) other legal facts. We note the phrase "other legal facts", which demonstrates the inexhaustibility of this list. This means that civil legal relations may arise both on the grounds provided by Article 11 of the Civil Code of Ukraine and on other grounds. This is partially disclosed in the following parts of the article, which, in particular, establish that civil rights and obligations may arise directly from acts of civil law, acts of state authorities, the Autonomous Republic of Crimea, local self-government bodies and court decisions. Also, the basis for the emergence of civil rights and obligations may be the onset or nonoccurrence of a certain event. Therefore, we can conclude that the grounds for the emergence of civil legal relations are a wide range of legal facts, different in nature, which are inexhaustible in nature, that is, their list is much broader than that which is enshrined in Article 11 of the Civil Code of Ukraine.

${ }^{8}$ Цивільний процес України : підруч. / В. О. Кучер та ін.; ред. В. О. Кучер. Львів : ЛьвДУВС, 2016. 
The basis for the emergence of civil procedural legal relations is much more difficult, and several researchers defined as the following set of elements: 1) norms of civil procedural law; 2) civil procedural legal capacity of participants in civil proceedings; 3 ) procedural legal facts. According to the works of these authors, the rule of law as a prerequisite for the emergence of civil procedural legal relations can be established exclusively by the state, is mandatory, has a general nature, regulates social relations exclusively in the field of administration of justice in civil cases, aims at comprehensive and timely consideration and resolution of civil cases etc. In turn, civil procedural legal capacity is the ability to have civil procedural rights and obligations ${ }^{9}$. Specificity of legal procedural facts is that such circumstances are directly related to the realization of the right to appeal to the court for the protection of violated or disputed subjective substantive law or interest, that is, with the opening of proceedings on the case in the trial court, stages of appeal or cassation proceedings to review decisions on newly discovered circumstances etc.

That is, the main difference between the grounds for the emergence of civil law and civil procedural legal relations is that for the emergence of the first only the presence of a legal fact is necessary. The list of legal facts clearly regulated by law, and it can be complemented by other legal facts, provided that they will contribute to the emergence of civil rights and obligations. In turn, the emergence of civil procedural legal relations implies the need to comply with several conditions at once. The presence of a legal fact, which, we note, in this case has its own specifics, is not the only reason for the emergence of civil procedural legal relations, because it is necessary to have an appropriate norm of law and legal capacity of the subject. Therefore, according to the criterion of the basis for the emergence of civil procedural legal relations is much more difficult on civil law.

4. A specific form in which the rights and respective obligations of the parties are expressed. In the context of civil relations, the form in which the rights and respective obligations of the parties are expressed is the deal, i.e. the action of a person aimed at acquisition, change or termination of civil rights and obligations. Deals can be unilateral and bilateral or multilateral (agreements). A unilateral transaction is the action of one party, which may be represented by one or more persons. Such deal creates obligations only for the person who has performed it, and for other persons the obligations can be created only in cases established by law or agreement with these persons. Accordingly, a two- or multilateral transaction is a concerted action by two or

\footnotetext{
2006.

${ }^{9}$ Мазур О. С. Цивільне право України : навч. пос. К.: Центр навчальної літератури,
} 
more parties. The deal may be made orally or in writing (electronically), and the parties are entitled to choose the form of the transaction, unless otherwise provided by law. The deal may be made orally or in writing (electronically), and the parties are given the right to choose the form of the deal, unless otherwise provided by law. The deal for which the law does not provide for a mandatory written form, shall be deemed to have been concluded if the conduct of the parties certifies their will to have the relevant legal consequences, and in cases stipulated by the contract or law, the will of the party to conclude the deal may be expressed in silence. In other words, the form in which the rights and respective obligations of the parties to civil relations are expressed is oral or written (electronic) transaction, and a mandatory written form may be established by law, but there is no rule of mandatory written nature.

The form in which the rights and respective obligations of the parties in civil procedural relations are expressed is a judicial decision. According to Article 258 of the Civil Procedural Code of Ukraine, court judgments are determinations, decisions, resolutions and court orders. By passing resolutions the court resolved the procedural issues associated with the movement of the case in the court of first instance, the motions and statements of persons participating in the case, the question to postpone consideration of the case, the ad break, stay or termination of proceedings, abandonment of the application without consideration, and other cases provided for by this Code. The decision of the court ends with the consideration of the merits of the case by the trial court. The judgment is adopted as a result of the review of court decisions in the appeal and cassation procedure. Accordingly, in cases defined by law, the court proceedings may result in a ruling or a court order. The form in which the rights and respective obligations of the parties to civil and procedural legal relations are expressed is considered to be the court decisions, since their content establishes the rights and obligations of the parties to the relevant proceedings (legal relations), which each party is obliged to fulfill and observe. Also, the court decision is the basis for the restoration of violated rights of the subject of civil relations.

Therefore, we conclude that civil law and civil procedural legal relations are characterized by different forms, in which the rights and obligations of the parties are expressed. If in the first case such a form is an oral or written transaction, that is, the action of a person aimed at the acquisition, change or termination of civil rights and obligations, the form of expression of rights and obligations of the parties to civil and procedural legal relations is a court decision.

5. The peculiarities of the subjective right. Features of the subjective right of participants in civil legal relations is enshrined in Article 13 of the Civil 
Code of Ukraine, according to which a person exercises civil rights within the limits provided by the contract or acts of civil law. In exercising his or her rights, a person is obliged to refrain from actions that could violate the rights of others or cause damage to the environment or cultural heritage. Not allowed actions of the person, committed with the intent to cause harm to another person, and also abuse of right in other forms. In the exercise of civil rights, a person must observe the moral principles of society. Civil rights may not be used to unduly restrict competition, abuse of a monopoly position in the market or unfair competition. If a person fails to comply with such requirements in the course of exercising his or her rights, the court may oblige him or her to stop abusing his or her rights and apply other consequences. That is, in civil law relations the essence of subjective law is primarily reduced to the right to one's own conduct. A person receives the scope of rights, which is limited by certain boundary requirements, according to which he or she controls his or her behavior.

Under article 4 of the Code of Civil Procedure, a person applies to the courts for protection of his or her violated, unrecognized or disputed rights, freedoms or legitimate interests. That is, the subjective right of a person in civil and procedural legal relations arises as a result of the formulation of the requirement of specific behavior from other persons to stop violating the rights and interests of the person and update it in the violated rights.

6. By the nature of the implementing entities of their rights. As we have already mentioned before, in civil relations a person realizes his civil rights freely, at his own discretion, but within the limits provided to him by the contract or acts of civil law. That is, the desire to implement civil law is sufficient for their implementation. At the same time, in bilateral civil relations, it is important for the realization of human rights that the other party fulfils its corresponding duty. For example, Article 901 of the Civil Code ${ }^{10}$ of Ukraine states that under the contract for the provision of services, one of the parties (the contractor) undertakes to provide a service at the request of the other party (the customer), which is consumed in the process of performing a certain action or carrying out certain activities, and the customer undertakes to pay the contractor specified service, if the other is not established by the contract. That is, a person's right to the service may be exercised only if another person fulfils his obligations.

A person's subjective right to participate in civil and procedural legal relations is realized by the person in accordance with Article 4 of the Civil Procedure Code of Ukraine by applying to the court for protection of his

${ }^{10}$ Цивільний кодекс України : Закон України від 16.01.2003 № 435-IV. Відомості Верховної Ради України. 2003. № 40. Ст. 356. 
violated, unrecognized or disputed rights, freedoms or legitimate interests. In this context, there is no need to coordinate their actions aimed at the implementation of subjective law in such legal relations with the other party. Everyone has such a right, and its desire to realize it does not depend on the other party.

Therefore, by the nature of implementation of subjective rights by the parties, civil and civil procedural legal relations also differ significantly. If civil legal relations are characterized by the interrelation between the realization of human rights and the fulfillment of other person's obligations, then in civil procedural legal relations any person realizes his rights at his discretion, but the final result of implementation does not depend on his will, because the decision in the civil process is made by the court.

7. On peculiarities of legal regulation. The academic literature on civil law notes that civil relations may arise on the basis of both legislation and other sources. B. Yanovitskaya and V.A. Kucher are the main legal regulators of civil legal relations: civil contract, founding document of a legal entity, custom, international contract, and in cases provided by law, and court precedent ${ }^{11}$. Researchers first of all emphasize the role of contracts in civil law self-regulation (part 1-3 of article 6 of the Civil Code of Ukraine) and constituent documents of legal entities (article 87 of the Civil Code of Ukraine). Thus, the peculiarity of legal regulation of civil legal relations is that it is carried out not only by the legislative way. At the same time, at the scientific level the role and importance of individual regulators - in particular, contracts and constituent documents of legal entities - are emphasized.

Regarding civil and procedural relations, all the procedures that they assume are clearly regulated and subject to unconditional execution by the parties of legal relations, because the legal regulation of civil and procedural legal relations is carried out by the norms of the Civil Procedural Code of Ukraine. It should be noted that if the legal regulation of civil legal relations is carried out by the norms of civil law and in other ways provided by law, the civil procedural relations are regulated exclusively by law.

Therefore, we conclude that the peculiarities of legal regulation of civil and civil procedural legal relations differ. Legal regulation of civil and procedural legal relations is carried out by law, and civil - by law, civil contract, constituent documents of the legal entity, customs, international treaties, judicial precedents.

${ }^{11}$ Цивільний процес України : підруч. / В. О. Кучер та ін.; ред. В. О. Кучер. Львів : ЛьвДУВС, 2016. 
8. At the time of existence. In Chapter 18 of the Civil Code of Ukraine ${ }^{12}$ it is established that both terms and conditions apply in civil relations. The term is a certain period in time, with the expiration of which is associated with an action or event of legal significance, and the period of time is a certain point in time, the onset of which is associated with an action or event of legal significance. The term is determined by years, months, weeks, days or hours, and the time period by the calendar date or an indication of an event that must inevitably occur. If the contract between the parties is concluded indefinitely, the end of the legal relationship may be linked to the occurrence of a certain event (e.g. the withdrawal of one of the parties from an indefinite contract). Thus, civil legal relations may exist within a certain period of time, before the deadline agreed upon by the parties (including the occurrence of a certain event) or indefinitely.

In turn, there are special procedural deadlines for civil and procedural legal relations. Thus, Chapter 6 of the Civil Procedural Code of Ukraine determines that the time limits within which procedural actions are performed are established by law, and if such time limits are not determined by law - are established by the court. From this we can conclude that in contrast to the civil law, in the civil procedural legal relations there are other rules for determining the terms and time of existence of legal relations. First of all, a number of terms are directly established in the norms of the Civil Procedure Code of Ukraine. For example, in part 1 of Article 170 it is established that the debtor has the right within fifteen days from the date of delivery of a copy of the court order and attached documents to submit an application for its cancellation to the court that issued it. Another example of the terms of civil and procedural legal relations is the indication in Article 43 of the Civil Procedural Code of Ukraine that the participants of the case are obliged to perform procedural actions within the time limits established by law or by the court. That is, in this case, there is no specific term of civil and procedural legal relations, but it is established that it can be regulated in the norms of the Civil Procedural Code of Ukraine (for example, as in the above example), and directly in the court decision. So, civil and procedural legal relations exist within the period specified in the legislation.

9. If necessary, interaction between the parties. As we have already repeatedly noted in this article, the interaction of the parties in civil legal relations is necessary because the overwhelming majority of the legal relations regulated by the norms of the Civil Code of Ukraine are bilateral, and therefore require the parties to fulfill their corresponding rights and

12 Цивільний кодекс України : Закон України від 16.01.2003 № 435-IV. Відомості Верховної Ради Украӥни. 2003. № 40. Ст. 356. 
obligations. Moreover, when entering into civil legal relations, the participants themselves are interested in interacting with each other and achieving the goal of their relations.

In the same time, not all parties may be interested in civil procedural legal relations, because they arise in connection with the need to protect violated, unrecognized or disputed rights, freedoms or legitimate interests. In civil and procedural legal relations involves a much larger number of subjects, and all the procedures provided for clearly regulated in the Civil Procedural Code of Ukraine, so each party is required, above all, strict compliance with the requirements established by law. That is, in civil and procedural legal relations the term "interaction of the parties" acquires a slightly different meaning. If interaction of subjects of civil legal relations is expressed in mutual performance by them of corresponding rights and duties with a view of achievement of the purpose of joint activity in civil procedural legal relations interaction represents performance by all parties of the established legislative instructions as a result of what they get the status of subjects of corresponding legal relations. In other words, the interaction of the parties in this case loses the sign of voluntariness and is expressed in the form of a legislatively established requirement to the behavior of certain subjects.

Consequently, the need for interaction between the parties is characteristic of both civil and civil procedural legal relations. However, in both cases it takes different forms, which we have established above.

10. Legal nature of relations (property or non-property). Both civil law and civil procedural legal relations can be both property and non-property, as confirmed by the previous study. It follows from the fact that such a character is inherent in civil legal relations. Since civil legal relations is the actual reason for the existence of civil procedural relations. We will come to the conclusion that they can also be characterized by both types of legal relations.

Thus, in the process of research we have established that the criteria of the ratio of civil and civil procedural legal relations should be divided into general and special ones.

We propose to express special criteria of the ratio of civil law and civil procedural legal relations in the following way:

1) in the circle of persons related to them - a much wider range of persons participates in civil and procedural legal relations;

2) on the object - civil and civil procedural legal relations are related as a prerequisite and as a consequence. It is not possible to violate this right or interest without it. Accordingly, the protection of violated rights and interests is the only object of civil and procedural legal relations; 
3) on the grounds of origin - the main difference between the grounds of appearance of civil and civil procedural legal relations is that for the emergence of the first only the presence of a legal fact is required;

4) in the specific form in which the rights and respective obligations of the parties are expressed - civil and civil procedural legal relations are characterized by various forms in which the rights and obligations of the parties are expressed;

5) by the peculiarities of subjective law - the essence of subjective law of the side of civil legal relations is reduced to the right to one's own behavior, and civil procedural legal relations - to the right to demand a specific behavior from other persons;

6) by the nature of implementation - civil and civil procedural legal relations also differ significantly;

7) in accordance with the peculiarities of legal regulation - civil and civil procedural legal relations are characterized by both clear regulation of procedures and establishment of legal regulation of occurrence, change and termination of subjective rights;

8 ) in the period of existence - civil and civil procedural legal relations also differ, but insignificantly. In civil legal relations, time is set clearly or by reference to the term, or the occurrence of a certain event, which is associated with the termination of legal relations. In turn, for civil procedural legal relations is characterized mainly by legislative establishment of terms or references to the definition of terms in court decisions;

9) if necessary, the need for interaction between the parties - the need for interaction between the parties is characteristic of both civil and civil procedural legal relations. However, in both cases it takes different forms;

10) by property or non-property nature - both civil and civil procedural legal relations can be both property and non-property. It follows from the fact that such a nature is inherent in civil legal relations. As the civil-legal relations are actually a prerequisite for the existence of civil-procedural, we come to the conclusion that they can also be characterized by both varieties.

\section{CONCLUSIONS}

Thus, studying the ratio of civil law and civil procedural legal relations, we came to the conclusion that both types of legal relations are very close and closely interacting, although they are characterized by a number of significant differences. Initially, their interrelation can be characterized as bilateral, since the emergence of civil procedural legal relations is associated with the controversial nature of civil legal relations. In turn, the existence of civil procedural legal relations is a guarantee of ensuring the functioning of civil legal relations. Therefore, in general terms, these legal relations correlate as such that constantly and closely interact with each other. 
Analyzing and correlating separate elements of both types of legal relations, we have made a conclusion that civil and civil procedural legal relations essentially differ, especially in a part of a subject structure, object of legal regulation, on the bases of occurrence, forms of expression, features of subjective rights, character of realisation and so forth. It testifies to the fact that despite the proximity and a number of close ties, civil law and civil procedural legal relations are not subject to identification and coexist as two full-fledged and independent legal institutions.

\section{SUMMARY}

The article deals with the analysis of the relationship between civil and civil procedure. The categories of civil and civil procedural law, civil and civil procedural norms are compared, as well as the concepts of civil and civil procedural relations are established. The connection between civil and civil proceedings has been established.

The author examines the features that are sectoral criteria for the relationship between civil and civil proceedings. The author has established the ratio of civil and civil legal relations according to certain criteria. They should be divided into general and special ones.

The author emphasizes that by examining the relationship between civil and civil proceedings, we have come to the conclusion that both types of legal relationships are very close and closely interacting, although they are characterized by a number of significant differences.

\section{REFERENCES}

1. Цивільний кодекс України : Закон України від 16.01.2003 № 435-IV. Відомості Верховної Ради України. 2003. № 40. Ст. 356.

2. Протокол № 11, який передбачає перебудову контрольного механізму, створеного Конвенцією про захист прав і основних свобод людини : Міжнародний документ від 11.05.1994 № 11. Офіційний вісник Украӥни. 1998. № 13. Ст. 291.

3. Великий тлумачний словник сучасної української мови (з дод. і допов.) / уклад. і голов. ред. В. Т. Бусел. К.; Ірпінь : ВТФ “Перун”, 2005. $1728 \mathrm{c}$.

4. Голубєва Н. Ю. Співвідношення зобов'язальних та речових правовідносин . Часопис иивілістики. 2015. Вип. 19. С. 13-17.

5. Діденко Л. В. Співвідношення цивільно-правових та цивільнопроцесуальних відносин. Науковий вісник Ужгородського національного університету. Серія: Право. 2016. Вип. 41. Т. 4. С. 146-149.

6. Кілічава Т. М. Цивільне процесуальне право : навч. посіб. К. : Центр учбової літератури. 2007. 352 с. 
7. Мазур О. С. Цивільне право України : навч. пос. К.: Центр навчальної літератури, 2006. 384 с.

8. Підлубна О. В. Співвідношення норм цивільного процесуального права і цивільного процесуального правовідношення. Вісник Хмельницького інституту регіонального управління та права. 2002. № 2. C. 237-240.

9. Теоретичні проблеми цивільного процесуального права : підручник / М. М. Ясинок, М. П. Курило, О. В. Кіріяк, О. О. Кармаза, С. І. Запара та ін.; за заг. ред. д.ю.н. професора М. М. Ясинка. К. : Алерта, 2016. $890 \mathrm{c}$.

10. Тичинська Л. А. Правові засади цивільного процесуального права: співвідношення з іншими галузями права в умовах розбудови правової держави. Свропейські перспективи. 2014. № 4. С. 121-123.

11. Цивільне право : підручник : у 2 т. / В. І. Борисова (кер. авт. кол.), Л. М. Баранова, Т. І. Бєгова та ін. ; за ред. В. І. Борисової, І. В. СпасибоФатєєвої, В. Л. Яроцького. Х. : Право, 2011. Т. 1. 656 с.

12. Цивільний процес України : підруч. / В. О. Кучер та ін.; ред. В. О. Кучер. Львів : ЛьвДУВС, 2016. 768 с.

13. Штефан М. Й. Цивільне процесуальне право України : академічний курс. К. : Ін Юре, 2005. 624 с.

\section{Information about the author:} Didenko L. V., $\mathrm{PhD}$, Associate Professor at the Department of Civil and Economic Law and Procedure, International Humanitarian University 33, Fontanska Road str., Odessa, 65009, Ukraine 